\title{
Biological and molecular evidences on host range of leaf curl begomovirus disease of sunflower (Helianthus annuus L.)
}

\author{
M. Vindyashree ${ }^{1}$, M. R. Govindappa ${ }^{2}$, V. N. Ghante ${ }^{2}$, D. S. Aswathanarayana ${ }^{1}$ and \\ I. Shankergoud ${ }^{2}$ \\ ${ }^{1}$ Department of Plant Pathology, University of Agricultural Sciences, Raichur-584104 (Karnataka), INDIA \\ ${ }^{2}$ All India Co-ordinate Research Project on Sunflower, Department of Plant Pathology, University of Agricultural \\ Sciences, Raichur-584104 (Karnataka), INDIA \\ *Corresponding author. E-mail: mrgpathology1@gmail.com
}

Received: November 8, 2014; Revised received: March 27, 2015; Accepted: May 14, 2015

\begin{abstract}
The present study was conducted to identify the alternate hosts of new leaf curl virus disease of sunflower. In the present study several crops and weed hosts were cross inoculated with leaf curl virus of sunflower under laboratory through insect vector whitefly (Bemisia tabaci), further all inoculated samples were retested (3-4 weeks after inoculation) by molecular based Polymerse chain reaction diagnosis for the presence of virus. The results revealed that the causal virus of the disease was successfully transmitted from sunflower to sunflower (Helianthus annuus), tomato (Solanum lycopersicum) and tobacco (Nicotiana tabacum L) and weed hosts such as Acanthospermum hispidum, Amaranthus viridis and Parthenium hysterophorus in a short incubation period (2-3 weeks after inoculation), while on other hosts Chilli (Capsicum annuum $\mathrm{L}$ ) and Datura stramonium, infection occurs in delayed incubation period. Further molecular analysis thorough polymerase chain reaction (PCR) diagnostic technique using virus specific primers also confirmed the presence of coat protein (CP) of leaf curl begomovirus in virus inoculated hosts viz., chilli, sunflower, tomato, and tobacco and weed hosts such as Acanthospermum hispidum, Amaranthus viridis, Datura stramonium and Parthenium hysterophorus. Thus, findings substantiate that the above hosts are major sources of the virus inoculum and served as potential alternate hosts of the disease during the off season.
\end{abstract}

Keywords: Begomovirus, Host range, Polymerase chain reaction, Sunflower, Whitefly

\section{INTRODUCTION}

Sunflower is one of the important edible oilseed crops grown in the world after soybean and groundnut and crop has gained importance due to its short duration of maturity, excellent quality oil, and photo-insensitivity and drought tolerance (Muhammad et al., 2012). In the world, sunflower being cultivated over an area of 20 million hectares and production around 30 million tonnes. In India, sunflower is being grown over an area of 0.72 million hectares with a production of 0.50 million tonnes. The major sunflower producing states in India are Karnataka (53.19\%), Andhra Pradesh $(20.83 \%)$ and Maharashtra $(14.58 \%)$ and in recent years, its cultivation is taken up in non-traditional states like Punjab, Haryana, Uttar Pradesh, Gujarat, Orissa, Madhya Pradesh and Rajasthan. Presently, Karnataka is the leading state in the country contributing 53.19 and 38.61 per cent of total area and production, respectively. It is the second important oilseed crop after groundnut having an area of 0.38 million hectares with production of 0.19 million tonnes. However, productivity $\left(503 \mathrm{~kg} \mathrm{ha}^{-1}\right)$ is lesser than the national average of $692 \mathrm{~kg} / \mathrm{ha}$ (Anonymous, 2013).
Although area under crop cultivation increased with the advent of new sunflower commercial genotypes and their wider adoptability to diverse agroclimatic conditions with low economic attention of farmers on plant protection measures, the crop has been found suffering from many diseases which included fungi and viral diseases (Ramaiah et al., 2001; Saharan et al., 2005). Among viral disease affecting sunflower, very recently leaf curl disease caused by begomovirus of the geminiviridae family was reported for the first time in India from Main Agricultural Research Station (MARS), University of Agricultural Sciences (UAS) campus, Raichur and the causal agent of the disease was confirmed as DNA begomovirus which is clustered next to tomato leaf curl Karnataka virus isolate Lucknow (ToLCKV-[Luc] (Accession no. EU604297.2) and Tomato leaf curl virus - Bangalore II (ToLCBV-[Ban2]) (Accession no. EU604297.2) and shared 97.5 per cent nucleotide identities (Govindappa et al., 2011). Further, viral full genome was sequenced and the analysis of the study revealed that, leaf curl virus having DNA-A and the associated satellite beta DNA components of 2761 and 1375 (Nucleotides) in length respectively. The DNA-A molecule shared 
maximum identity with tomato leaf curl Karnataka clone IKH12 (ToLCKV- IKH12) (Vanitha et al., 2013).

Although several reports revealed that whitefly transmitted geminiviruses (Geminiviridae, Begomovirus) are economically important pathogens causing serious losses in food crops globally. The emergence of the B. tabaci geminivirus complex around the world depends on various factors, such as evolution of variants of the viruses, changes in the biology of vectors, movement of infected planting materials, sources of volunteer and weed hosts plants, introduction of new crops and host susceptibility genes through the exchange of germplasm, changes in cropping systems and climatic factors (Ramappa et al., 1998; Varma and Malathi, 2003). Host range studies revealed by Muniyappa et al. (2000) with tomato leaf curl virus (ToLCV), pumpkin yellow vein mosaic in pumpkin (Maruthi et al., 2007), hibiscus leaf curl virus in hibiscus (Rajeshwari et al., 2005) and croton leaf curl virus in cotton (Mahesh et al., 2010) indicated that begomoviruses have wide host compatibility, however their infection and further symptoms expression varied between the host plants. Although, leaf curl disease on sunflower being the first occurrence of begomovirus on sunflower crop from south India, meagre research efforts are made in relevance to identification of alternate hosts of the virus by biological and molecular means in relation to its survival is not been understood properly. Hence, the present study was conducted to find out the alternate hosts of the causal virus based on biological and molecular assay in relation to disease spread.

\section{MATERIALS AND METHODS}

Maintenance of sunflower leaf curl virus (SuLCV) culture: Sunflower plants showing characteristic leaf curl virus symptoms of vein thickening, upward leaf curling, enation and stunted growth was brought to the laboratory from sunflower fields of Main Agricultural Research Station, University of Agricultural Sciences, Raichur, and virus culture was maintained by inoculating 8-10 days old healthy sunflower seedlings using whiteflies (B. tabaci). All process was carried out under nylon net (40 mesh) protected greenhouse.

Maintenance of whitefly culture: Initially, whiteflies (B. tabaci) were collected from sunflower plants at Main Agricultural Research Station (M.A.R.S), Raichur and the colony was established on freshly grown cotton (Gossypium hirsutum) plants kept in an insect proof net house. Four weeks after release, freshly emerged whiteflies were collected using an aspirator and were transferred to healthy cotton plants kept in an insect proof cages. The colony so developed was referred to be virus free (a-viruliferous) colony and further same colony was periodically maintained by frequently introducing healthy cotton plants grown in pots $(6 \times 10 \mathrm{~cm})$ into the insect proof cages maintained in an insect proof polyhouse of controlled temperature of 28 to $30^{\circ} \mathrm{C}$.

Biological confirmation of alternate hosts of the virus: For this study, healthy seedlings of different cultivated crop plants viz., bhendi (Abelmoschus esculentus), cotton (Gossypium hirsutum cv), chilli (Capsicum annuum), greengram (Vigna radiata), horsegram (Dolichous biflorus), tobacco (Nicotiana tabacum) and tomato (Solanum lycopersicum) and several weed hosts such as Acanthospermum hispidum, Ageratum conyzoides, Amaranthus viridis, Cassia tora, Croton bonplandianum, Datura stramonium, Euphorbia geniculata, Euphorbia hirta, Parthenium hysterophorus and Phylanthus niruri were raised in polythene bags contained soil mixture of FYM and sand. Seedlings of respective hosts were cross inoculated with virus using $B$. tabaci at two leaf stage. For inoculation study, healthy whiteflies were collected from culture house and allowed to feed on sunflower leaf curl diseased plant for $24 \mathrm{hrs}$ as an acquisition access period (AAP). Such whiteflies were collected and inoculated onto test seedlings which were further allowed to feed on healthy host for $24 \mathrm{hrs}$ of inoculation access period (IAP). The virus inoculated seedlings of the respective hosts were kept in insect proof glasshouse for symptom expression. Observation was made on per cent transmission, time to initial and final symptoms expression and type of symptoms on each host. For each host, healthy seedlings were maintained in an insect proof cage without inoculation of the virus for comparison studies.

Molecular confirmation of leaf curl virus in weeds and crop plants: Further, 3-4 weeks after virus inoculation, all viruses cross inoculated crop plants and weed hosts were subjected to polymerase chain reaction (PCR) analysis for leaf curl virus detection using begomovirus specific primers. For the PCR analysis, initially total genomic DNA of the inoculated and uninoculated test plants were extracted by following CTAB (Cetyl Trimethyl Ammonium Bromide) method of Lodhi et al. (1994). Set of begomovirus coat protein specific primers 5' GCC(C/T)AT(G/A)TA(T/ C)AG(A/G)AAGCC(A/C)AG 3' (AV494) and 5' G(A/ G)TT(A/G/T)GA(G/A)GCATG(T/A/C)GTACATG 3' (AC1048) (Wyatt and Brown, 1996) which were capable of amplifying the core coat protein $(\mathrm{CP})$ region of many begomoviruses (Brown et al., 2001; Briddon et al, 2002; Chowda Reddy et al., 2005; Rajeshwari et al., 2005) and hence in the present study similar primers were used for detection of virus in inoculated and unicnoculated test samples. PCR reaction was carried out in $25 \mu \mathrm{l}$ reaction mixture containing $6.0 \mathrm{mM}$ Tris $\mathrm{HCl}, 2.5 \mathrm{mM}$ dNTPs, $20 \mu \mathrm{M}$ of each primer, 2.5 units of Tac DNA polymerase (Bangalore Genie Pvt. Ltd., Bangalore) and $10-15 \mu \mathrm{g}$ of DNA of the respective samples. PCR was performed in therocycler (Eppendorf, Camridge, UK) according to Wyatt and Brown (1996). The PCR protocol consisted of 2 min- 
M. Vindyashree et al. / J. Appl. \& Nat. Sci. 7 (1) : 381 - 387 (2015)

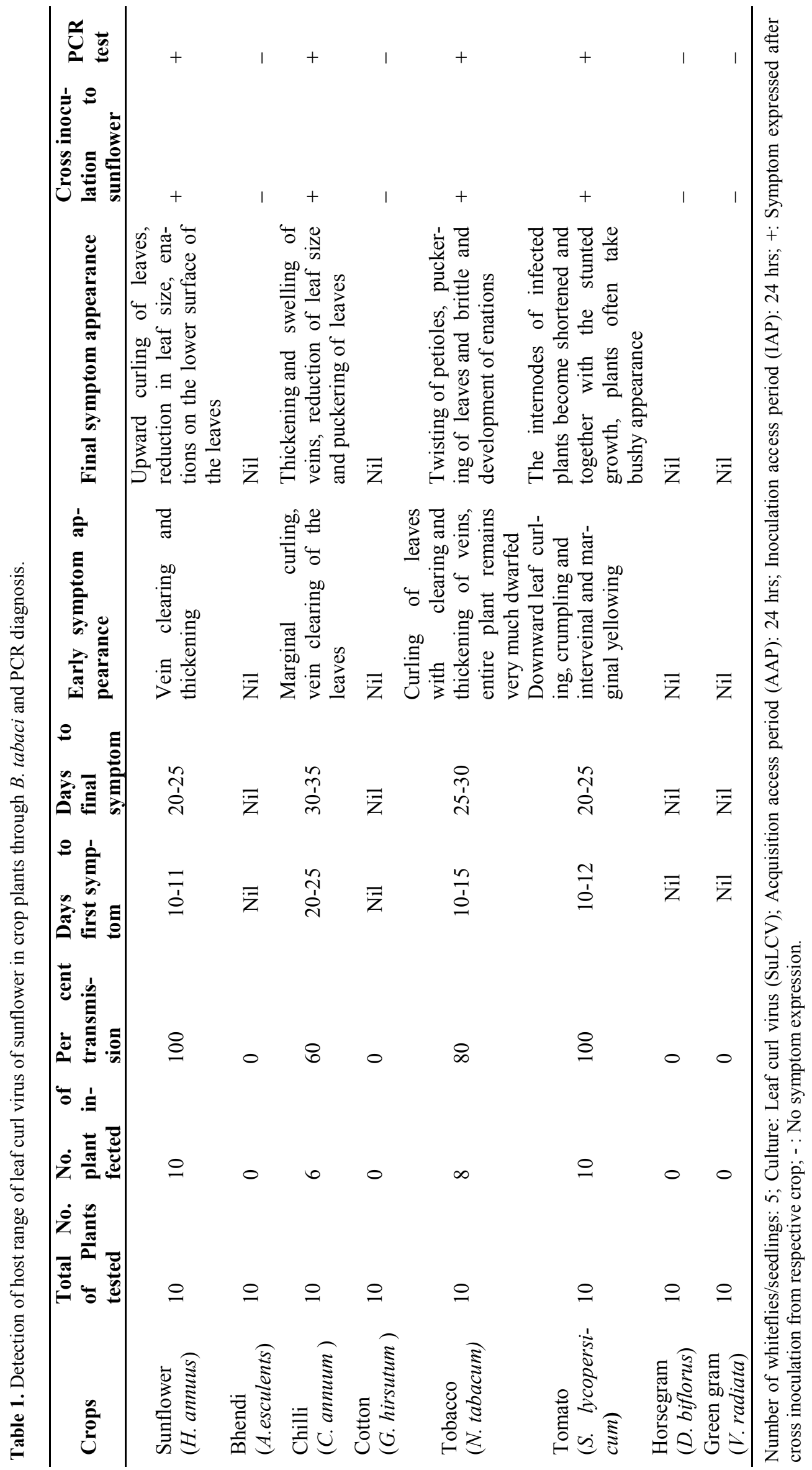




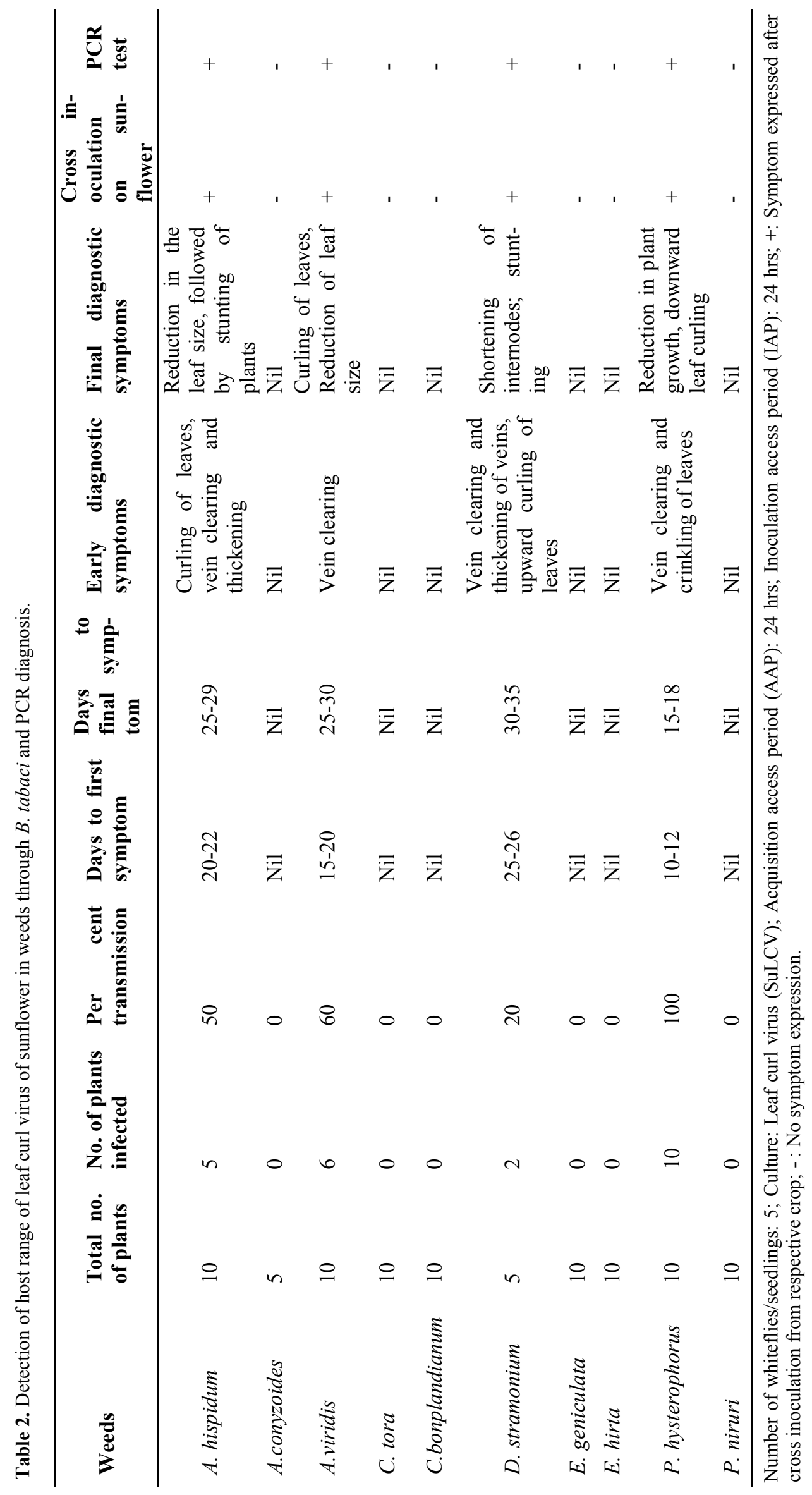




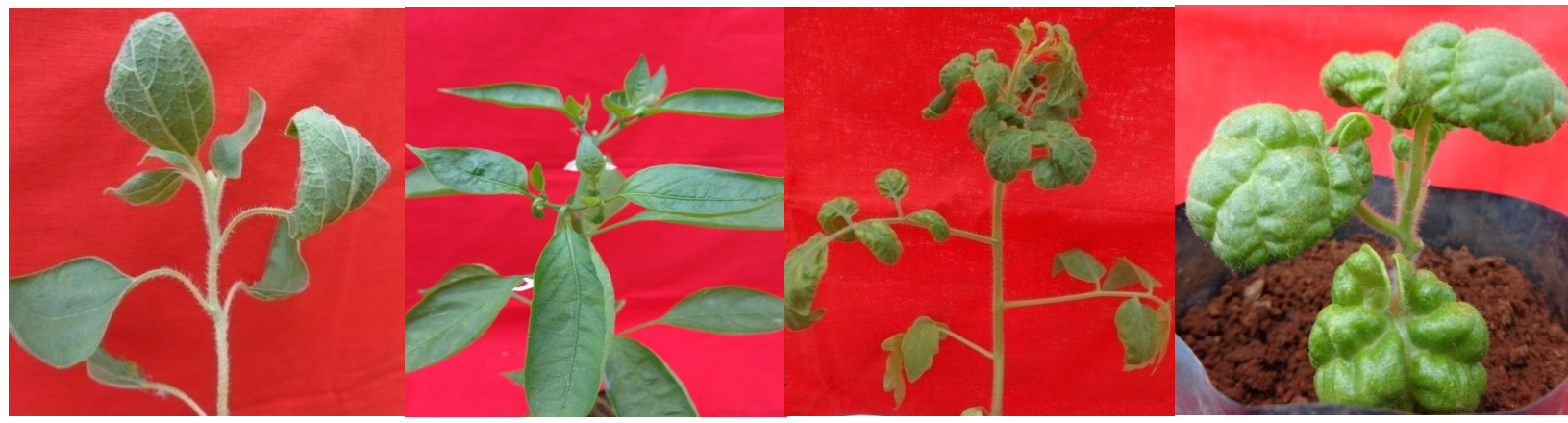

N. tabaccum

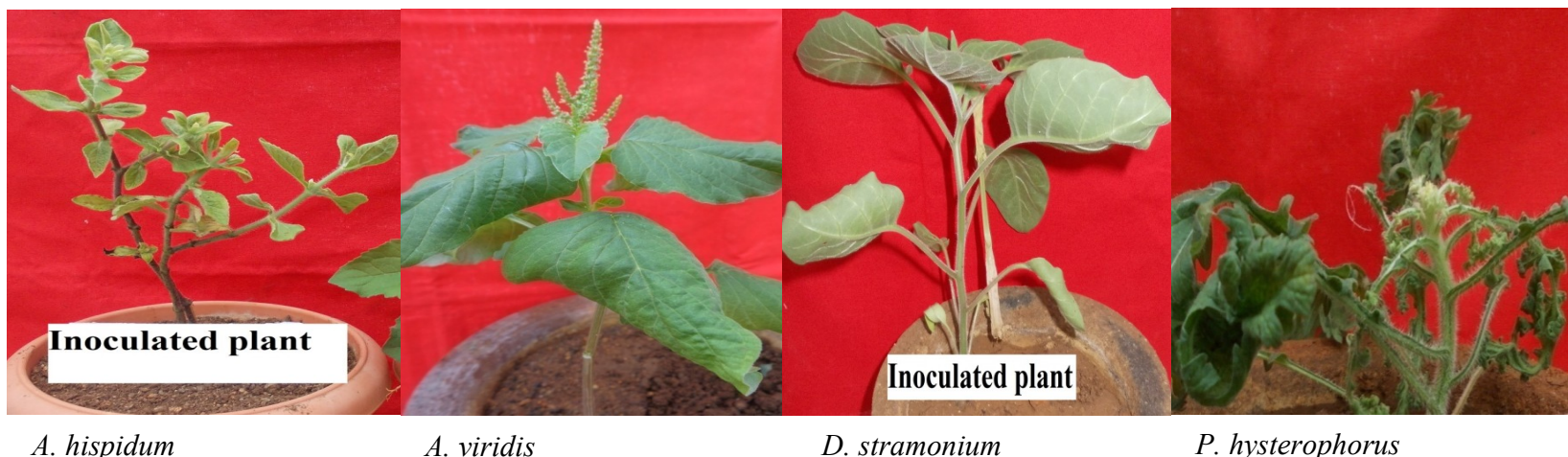

Fig. 1 . Expression of leaf curl virus symptoms on crops and weeds upon inoculation through whitefly B. tabaci

utes at $94^{\circ} \mathrm{C}$ (Initialisation step) followed by 30 cycles of $1 \mathrm{~min}$ at $94^{\circ} \mathrm{C}$ (Denaturation step), $1 \mathrm{~min}$ at $61^{\circ} \mathrm{C}$ (Annealing step), $2 \mathrm{~min}$ at $72^{\circ} \mathrm{C}$ (Extension step) and finally $10 \mathrm{~min}$ at $72^{\circ} \mathrm{C}$ (Final hold). Later PCR amplified products were separated by electrophoresis on $1 \%$ agarose gel and DNA fragments were visualised using ethidium bromide stain and analysed by alpha imager gel documentation system. DNA ladder set $(1 \mathrm{~Kb}, \mathrm{MBI}$ Fermentas, Germany) was included as sized molecular marker.

\section{RESULTS AND DISCUSSION}

Host range studies of virus inoculum through biological approach by using insect vector whitefly $B$. tabaci revealed that the virus was successfully transmitted to only four crop species and four weeds (Tables 1and 2). Among the cultivable crops tested, three crops viz., sunflower (H. annuus), tomato (L. solanacearum) and tobacco sp ( $N$. benthamiana) were found infected and exhibited leaf curl virus symptoms in a short incubation period of 2-3 weeks. While chilli (C. annum) found delayed in expression of symptoms. Among the weed species tested, successful transmission of virus was obtained only with Acanthospermum hispidum, Amaranthus viridis, Datura stramonium and Parthenium hysterophorus (Fig. 1). However A. hispidum, A. viridis and Parthenium hysterophorus could induce early symptom expression as compared to other weeds tested. This difference in expression of virus symptoms could be associated with the insect preference and also due to host biochemical compositions interfere with virus multiplications (Colvin et al., 2006; Sharma et al., 2008). Similarly tomato leaf curl begomovirus (ToLCV) from tomato was successfully transmitted to weeds by $B$. tabaci in a varied period of incubation with A. hispidum, Ageratum conyzoides, Bidens biternata, Conyza stricta, Datura stramonium, Euphorbia geniculata, Oxalis corniculata, P. hysterophorus, Solanum nigrum, Sonchus brachyotis, Stachyterpicta indica and Synedrella nodiflora and tobacco (N. Benthamiana) (Ramappa et al., 1998). In addition, leaf curl begomovirus of Hibiscus plant found infecting weeds (Ageratum conyzoides, Croton bonplandianum and Euphorbia geniculata) and tobacco species such as $N$. benthamiana, $N$. glutinosa

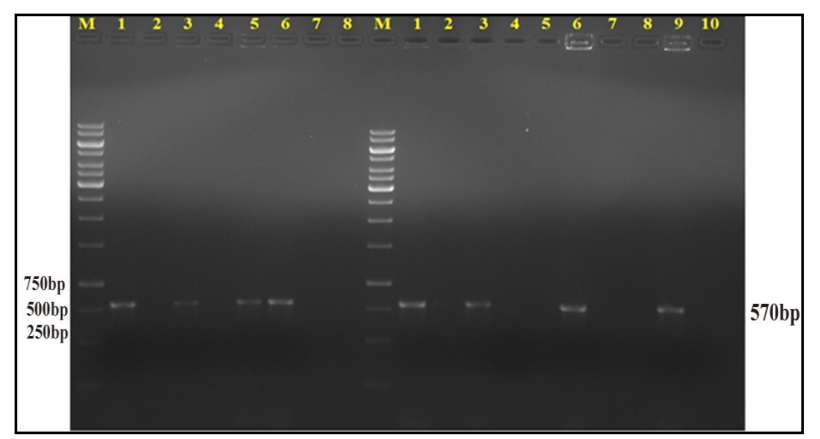

Fig. 2. Agarose gel showing the PCR amplified products (570 bp) obtained with the CP primer of begomovirus in selected crops and weeds. M: 1 KB Ladder; 1: Sunflower, 3: Chilli; 5: tomato; 6: Tobacco; M: $1 \mathrm{~KB}$ Ladder; 1: A. viridis; 3: A. hispidum; 6: D. stramonium; 9: P. hysterouphorus. 
a

N. tabacum (var. Samsun), cotton and tomato (Rajeshwari et al., 2005). The hosts confirmed with the tomato leaf curl begomovirus in tomato (ToLCV) (Ramappa et al., 1998) and begomovirus of Hibiscus were similar with the present findings as the virus infecting sunflower crop is belongs to begomovirus of the family geminiviridae. In the earlier molecular evidences, leaf curl virus on sunflower which has shared highest coat protein nucleotide identity (97\%) with tomato leaf curl Karnataka clone IKH12 (ToLCKV- IKH12) (Govindappa et al., 2011 and Vanitha et al., 2013). Further in the present investigations, leaf curl virus infection was further confirmed in all virus infected hosts such as sunflower, chilli, tomato and tobacco and weed hosts such as $A$. hispidum, A. viridis, D. stramonium and P. hysterophorus by molecular diagnostic polymerase chain reaction technique using virus coat protein $(\mathrm{CP})$ primers with the amplified PCR product of size $\sim 575$ bp (Fig. 2). These primers were specially designed to amplify the conserved region of the $\mathrm{CP}$ gene of begomoviruses infection in several crops employed by many workers (Muniyappa et al., 2000; Brown et al., 2001; Briddon et al., 2002; Chowda Reddy et al., 2005; Maruthi et al., 2007) to confirm the association of begomoviruses in wide range of crop plants. Further, these primers used elsewhere for detection of begomovirus such as leaf curl disease in Hibiscus (HLCuD) (Rajeshwari et $a l ., 2005)$ and mosaic disease of jatropha (Narayana et al., 2007), leaf curl virus ( $\mathrm{CrLCuV}$ ) disease in Croton (Mahesh et al., 2010). Hence, biological and molecular evidence proved that the crops such as chilli, sunflower, tomato, and tobacco and weed viz., A. hispidum, $A$. viridis, D. stramonium and $P$. hysterophorus are major potential alternate hosts of the virus inoculum.

\section{Conclusion}

Host range studies of the virus inoculum of leaf curl virus disease of sunflower through biological and molecular approach revealed that among different plant species tested, crops such as Sunflower, chilli, tomato and tobacco acted as potential reservoir hosts. Apart from cultivated crops, weed species viz., Acanthospermum hispidum, Amaranthus viridis, Datura stramonium and Parthenium hysterophorus also confirmed as potential sources of virus inoculum.

\section{REFERENCES}

Anonymous (2013). Sunflower Annual Report, All India Coordinated Research Project on Sunflower, Directorate of Oilseed Research, Rajendranagar, Hyderabad, pp 359.

Briddon, R. W., Bull, S. E., Mansoor, S, Amin, I. and Markham, P. G. (2002). Universal primers for the PCRmediated amplification of DNA beta: a molecule associated with some monopartite begomoviruses, Mol. Bio- technol., 20(3): 315-318

Brown, J. K., Idris A. M., Torres-Jerez, I., Banks, G. K. and Wyatt, S. D. (2001). The core region of the coat protein gene is highly useful in establishing the provisional identification and classification of begomoviruses. Arch. Virol., 146: 1581-1598.

Chowda Reddy, R. V., Colvin, J., Muniyappa, V. and Seal, S. (2005). Diversity and distribution of begomoviruses infecting tomato in India. Arch. Virol.150: 845-867.

Colvin, J., Omango, C. A., Govindappa., M. R., Stevenson, P. C., Maruthi, M. N., Gibson, G., Seal, S.E., and Muniyappa, V. (2006). Host plant Viral infection effects on arthropod vector population growth, development and behavior: Management and epidemiological implications, Advances in Virus research, (67) :420-453.

Govindappa, M. R., Shankergoud, I., Shankarappa, K. S., Wickramaarachchi, W. A. R. T., Anjeneya Reddy, B. and Rangaswamy, K. T. (2011). Molecular detection and partial characterization of begomovirus associated with leaf curl disease of sunflower (Helianthus annuus) in Southren India. Plant Pathology Journal, 10(1):2935.

Lodhi, M. A., Ye, G. N., Weeden, N. F. and Reisch, B. (1994.) A simple and efficient method for DNA extraction from grapevine cultivars and Vitis species. Pl. Mol. Biol. Rep., 12: 6-13.

Mahesh, Y. S., Shankarappa, K. S., Rangaswamy, K. T., Prameela, H. A., Aswathanarayana, D. S., Divya, B. L., Nagesha, N., and Maruthi, M. N. (2010). Detection and characterization of a Begomovirus associated with leaf curl disease of ornamental croton (Codiaeum variegatum). J. Hort. Sci. Biotech., 85: 101-105.

Maruthi, M. N., Rekha, A. R. and Muniyappa, V. (2007). Pumpkin yellow vein mosaic disease is caused by two distinct begomoviruses: complete viral sequences and comparative transmission by an indigenous Bemisia tabaci and the introduced B- biotype. EPPO Bull., 37 (2): 412-419.

Muhammad, W. A., Muhammad S. A. and Hammad, N. T, (2012). Combining ability analysis for achene yield and related traits in sunflower (Helianthus annuus L.). Chilean Journal of Agricultural Research., 72(1): 21-26.

Muniyappa, V., Venkatesh, H. M., Ramappa, H. K., Kulkarni, R. S., Zeidan, M., Tarba, C. Y., Ghanim, M. and Czosnek, H. (2000). Tomato leaf curl virus from Bangalore (ToLCV-Ban4): sequence comparison with Indian ToLCV isolates, detection in plants and insects, and vector relationships. Arch. Virol., 145: 1583-1598.

Rajeshwari, R., Reddy, R. V. C., Maruthi, M. N., Colvin, J., Seal, S. E. and Muniyappa, V. (2005). Host range, vector relationships and sequence comparison of a begomovirus infecting hibiscus in India. Annals of Applied Biology, 147: 15-25.

Ramappa, H. K., Muniyappa, V. and Colvin, J. (1998). The contribution of tomato and alternative host plants to tomato leaf curl virus inoculums pressure in different areas of south India. Annals of Applied Biology, 88: 369 $-387$.

Ramaiah, M., Bhat, A. I., Jain, R. K., Pant, R. P., Ahlawat, Y. S., Prabhakar, K. and Varma, A. (2001). Partial characterization of an Isometric virus causing Sunflower Necrosis Disease. Indian Phytopathology, 54: 246-250

Saharan, G. S., Naresh Mehta. and Sangwan, M. S. (2005). Diseases of oil seed crops, ISBN-81-7387-176-0, Indus publishing company, New Delhi, pp.38. 
Sharma, R. K., Gupta, V. K., Jindal. J. and Dilawari, V. K. (2008). Host associated genetic variations in whitefly Bemisia tabaci (Genn.), Indian J. Biotechnology, 7: 366 -370 .

Vanitha, L.S., Shankarappa, K.S., Rangaswamy, K.T., Wickramaarachchi W.A.R.T. and Govindappa, M.R. (2013). Complete Nucleotide Sequence of Tomato Leaf Curl
Karnataka Virus and $\beta$ Satellite Molecule Associated with Leaf Curl Disease on Sunflower in India. Plant Pathology Journal, 12: 19-25.

Varma, A. and Malathi, V. G. (2003). Emerging geminivirus problems: A serious threat to crop production. Annals of Applied Biology, 142: 145-164. 